\title{
Correlation between fibre content of the lung and disease in east London asbestos factory workers
}

\author{
J C WAGNER, ' M L NEWHOUSE, ${ }^{2}$ B CORRIN, ${ }^{3}$ C E R ROSSITER, ${ }^{2}$ D M GRIFFITHS \\ From the MRC Pneumoconiosis Research Unit, ${ }^{1}$ Penarth, TUC Centenary Institute of Occupational Health, ${ }^{2}$ \\ London School of Hygiene and Tropical Medicine, and the London Chest Hospital, ${ }^{3}$ London, UK
}

\begin{abstract}
The lungs from 36 past workers at an east London asbestos factory who had died from asbestos related disease were compared with lung tissue from 56 matched control patients being operated on in east London for carcinoma of the lung, correlating the severity of asbestosis and the presence of pulmonary carcinoma or mesothelioma of the pleura or peritoneum with an asbestos exposure index and type and amount of mineral fibre in the lungs. Asbestosis was associated with far heavier fibre burdens than mesothelioma. There was also a striking difference in the degree of asbestosis between the subjects with mesothelioma and those with carcinoma of the lung, the asbestosis being more severe in the latter. A further finding was that crocidolite and amosite were strongly associated with asbestosis, carcinoma of the lung complicating asbestosis, and mesothelioma, whereas no such correlation was evident with chrysotile or mullite. it is suggested that more emphasis should be placed on the biological differences between amphibole and serpentine asbestos fibre.
\end{abstract}

A study of the asbestos fibre content of the lungs of past workers at a Royal Naval dockyard showed a good correlation between the total lung fibre content and the severity of asbestosis. ${ }^{\prime}$ Furthermore, mesotheliomas occurred most commonly in those subjects with minimal or slight asbestosis, by contrast with pulmonary carcinomas that were commoner in those with the more severe grades of asbestosis. We have now conducted a similar study on a group of asbestos workers with a different type of asbestos exposure.

\section{Materials and methods}

The study group comprised 36 past workers at a factory in east London who had been employed manufacturing asbestos textiles, sectional asbestos piping, and other asbestos products before the introduction of the 1969 Asbestos Regulations. Crocidolite, chrysotile, and amosite were all used extensively at the factory; crocidolite until the late 1950s and chrysotile and amosite until the factory closed in 1968. At the factory all fibre was received in bales and opened and disintegrated before use, whereas at the dockyard prefabricated asbestos

Accepted 11 May 1987 material was used, except in the mattress shop and the crocidolite spraying of bulkheads. The mortality of workers at this factory has been described. ${ }^{2}$

The subjects in the present study had died between 1976 and 1984 and after postmortem examinations had been conducted on behalf of various coroners in south east England their lungs had been submitted to the London Boarding Centre for Respiratory Diseases (formerly the Pneumoconiosis Medical Panel). Three standard pieces of lung tissue measuring $5 \times 5 \times$ $3 \mathrm{~cm}$, two from the base and one from the lateral border of a lower lobe, were selected. After taking a $2 \times 2 \times 0.5 \mathrm{~cm}$ block for light microscopy, the remainder was digested in potassium hydroxide and the mineral fibre content assessed quantitatively and qualitatively by analytical electron microscopy.' Asbestosis was graded as minimal, slight, moderate, or severe.

The subjects were identified as former factory workers by matching the name, forename, and date of birth on the postmortem records with the records held by MLN of past workers at this factory, including the dates of first and last employment at the factory and the jobs held there. ${ }^{3}$ Exposure was graded 1-6 according to the degree of dust exposure involved in a particular job. Laggers were judged to have had severe 
Table 1 Proportions of cases in each diagnostic category by degree of asbestosis

\begin{tabular}{|c|c|c|c|c|}
\hline & $\begin{array}{l}\text { Carcinoma lung } \\
\text { (14) }\end{array}$ & $\begin{array}{l}\text { Pleural } \\
\text { mesothelioma (9) }\end{array}$ & $\begin{array}{l}\text { Peritoneal } \\
\text { mesothelioma }(10)^{*}\end{array}$ & $\begin{array}{l}\text { Asbestosis } \\
\text { (3) }\end{array}$ \\
\hline $\begin{array}{l}\text { Minimal } \\
\text { Slight } \\
\text { Moderate } \\
\text { Severe }\end{array}$ & $\begin{array}{c}0 \\
21 \cdot 4 \\
42 \cdot 9 \\
35 \cdot 7\end{array}$ & $\begin{array}{l}22 \cdot 2 \\
33 \cdot 3 \\
33 \cdot 3 \\
11 \cdot 1\end{array}$ & $\begin{array}{l}11 \cdot 1 \\
55 \cdot 6 \\
22 \cdot 2 \\
11 \cdot 1\end{array}$ & $\begin{array}{c}0 \\
0 \\
33 \cdot 3 \\
66 \cdot 7\end{array}$ \\
\hline
\end{tabular}

*Degree of asbestosis was not recorded for one case.

exposure, graded 6 . Grades 4-5 related to production workers, grade 3 to maintenance men and engineers, and grades 1 and 2 to workers with little exposure-for example, those employed in canteens and stores. A subject who had held various jobs in the factory was graded by the highest exposure category in which he or she had worked. An exposure index was produced by multiplying exposure grade by the number of months an individual had worked at the factory.

A control group comprised 56 patients operated on at the London Chest Hospital in 1983-4 for carcinoma of the lung. These patients had never been occupationally exposed to asbestos and generally lived in east London. Seemingly normal lung tissue was taken from the surgical specimens received from these patients and examined in the same way as that from the study group.

Table 2 Mean fibre content per diagnostic category

\begin{tabular}{lrc}
\hline Category & No & Mean total fibre $\times 10^{6} / \mathrm{g}$ \\
\hline Controls & 56 & 35.8 \\
Carcinoma lung & 14 & 1141.7 \\
Pleural mesothelioma & 9 & 262.9 \\
Peritoneal mesothelioma & 10 & 565.7 \\
Asbestosis & 3 & 1720.7 \\
\hline
\end{tabular}

\section{Results}

The control group consisted of 44 men and 12 women, whereas the study group comprised 25 men and 11 women. The mean age of the controls at the time of their operation and the mean age of the study cases at death was similar, 61 and 62 respectively.

In the factory group there were 19 deaths from mesothelioma (nine pleural, 10 peritoneal), 14 from carcinoma of the lung, and three from asbestosis. Asbestosis was associated with every cancer but there was a noticeable difference in the degree of asbestosis according to the type of tumour. Subjects with mesothelial tumours often showed minimal or slight asbestosis, whereas those dying of carcinoma of the lung usually showed moderate or severe asbestosis (table 1).

Table 2 shows the mean total fibre count for the controls and each diagnostic category. The heaviest fibre content was found in those dying of certified asbestosis and lung cancer. The counts in the lungs from the pleural and peritoneal mesothelioma necropsies were considerably lower. The mean fibre content of the three asbestosis lungs was nearly 50 times greater than that found in the controls. Counts of each fibre type were made on each lung examined and the proportion of each fibre calculated; the mean of these

Table 3 Mean percentage distribution of fibre type by diagnostic category

\begin{tabular}{|c|c|c|c|c|c|}
\hline & Control & $\begin{array}{l}\text { Carcinoma } \\
\text { lung }\end{array}$ & $\begin{array}{l}\text { Pleural } \\
\text { mesothelioma }\end{array}$ & $\begin{array}{l}\text { Peritoneal } \\
\text { mesothelioma }\end{array}$ & Asbestosis \\
\hline $\begin{array}{l}\text { Amosite } \\
\text { Crocidolite } \\
\text { Chrysotile } \\
\text { Mullite } \\
\text { Other fibres }\end{array}$ & $\begin{array}{r}2 \cdot 6 \\
2 \cdot 8 \\
25 \cdot 9 \\
64 \cdot 4 \\
4 \cdot 4\end{array}$ & $\begin{array}{r}30.4 \\
56.7 \\
6.9 \\
5.2 \\
0.9\end{array}$ & $\begin{array}{r}39 \cdot 3 \\
20 \cdot 2 \\
17 \cdot 0 \\
20 \cdot 7 \\
2 \cdot 8\end{array}$ & $\begin{array}{r}17 \cdot 8 \\
53.9 \\
13.3 \\
14.6 \\
0.4\end{array}$ & $\begin{array}{r}17 \cdot 7 \\
60 \cdot 1 \\
4 \cdot 0 \\
17 \cdot 9 \\
0.3\end{array}$ \\
\hline
\end{tabular}

Table 4 Mean percentage constitution of asbestos by grades of asbestosis

\begin{tabular}{|c|c|c|c|c|c|c|}
\hline $\begin{array}{l}\text { Asbestosis } \\
\text { grade }\end{array}$ & $\begin{array}{l}\text { Total fibres } \\
\left(10^{6} / \mathrm{g}\right)\end{array}$ & $\begin{array}{l}\text { Amosite } \\
(\%)\end{array}$ & $\begin{array}{l}\text { Crocidolite } \\
(\%)\end{array}$ & $\begin{array}{l}\text { Chrysotile } \\
(\%)\end{array}$ & $\begin{array}{l}\text { Mullite } \\
(\%)\end{array}$ & $\begin{array}{l}\text { Other } \\
\text { fibres (\%) }\end{array}$ \\
\hline $\begin{array}{l}\text { Controls }(n=56) \\
\text { Minimal }(n=3) \\
\text { Slight }(n=11) \\
\text { Moderate }(n=12) \\
\text { Severe }(n=9)\end{array}$ & $\begin{array}{r}35 \cdot 8 \\
77 \cdot 7 \\
373 \cdot 4 \\
753 \cdot 8 \\
1735 \cdot 6\end{array}$ & $\begin{array}{r}2 \cdot 6 \\
12 \cdot 3 \\
22 \cdot 4 \\
36 \cdot 8 \\
25 \cdot 8\end{array}$ & $\begin{array}{r}2 \cdot 8 \\
32 \cdot 2 \\
37 \cdot 6 \\
50 \cdot 9 \\
62 \cdot 5\end{array}$ & $\begin{array}{r}25.9 \\
35 \cdot 5 \\
18 \cdot 2 \\
3 \cdot 7 \\
4 \cdot 0\end{array}$ & $\begin{aligned} 64 \cdot 4 \\
18 \cdot 7 \\
21 \cdot 1 \\
7 \cdot 0 \\
6.7\end{aligned}$ & $\begin{array}{l}4 \cdot 4 \\
1 \cdot 2 \\
0 \cdot 8 \\
1 \cdot 6 \\
1 \cdot 1\end{array}$ \\
\hline
\end{tabular}


Table 5 Exposure index and mean \% constitution of fibres

\begin{tabular}{|c|c|c|c|c|c|c|}
\hline $\begin{array}{l}\text { Exposure } \\
\text { index }\end{array}$ & $\begin{array}{l}\text { Total fibres } \\
\left(10^{6} / \mathrm{g}\right)\end{array}$ & $\begin{array}{l}\text { Amosite } \\
(\%)\end{array}$ & $\begin{array}{l}\text { Crocidolite } \\
(\%)\end{array}$ & $\begin{array}{l}\text { Chrysotile } \\
(\%)\end{array}$ & $\begin{array}{l}\text { Mullite } \\
(\%)\end{array}$ & $\begin{array}{l}\text { Other } \\
\text { fibres (\%) }\end{array}$ \\
\hline $\begin{array}{l}0 \text { (controls) }(\mathrm{n}=56) \\
<100(\mathrm{n}=8) \\
100-500(\mathrm{n}=12) \\
501-1000(\mathrm{n}=6) \\
1001-2560(\mathrm{n}=10)\end{array}$ & $\begin{array}{r}35 \cdot 8 \\
136 \cdot 7 \\
697 \cdot 7 \\
733 \cdot 4 \\
1530 \cdot 3\end{array}$ & $\begin{array}{r}2 \cdot 6 \\
8 \cdot 4 \\
32 \cdot 2 \\
23 \cdot 0 \\
41 \cdot 9\end{array}$ & $\begin{array}{r}2 \cdot 8 \\
45 \cdot 3 \\
42 \cdot 1 \\
46 \cdot 8 \\
54 \cdot 6\end{array}$ & $\begin{array}{r}25.9 \\
20.4 \\
10.0 \\
17 \cdot 1 \\
0.8\end{array}$ & $\begin{array}{r}64 \cdot 4 \\
25 \cdot 1 \\
14 \cdot 1 \\
12 \cdot 3 \\
1 \cdot 5\end{array}$ & $\begin{array}{l}4 \cdot 4 \\
0 \cdot 8 \\
1 \cdot 6 \\
0 \cdot 8 \\
1 \cdot 2\end{array}$ \\
\hline
\end{tabular}

proportions is shown in table 3. The contrast between the proportion of amphibole asbestos in the controls and the other categories is striking, less than $6 \%$ in the former but ranging between $60 \%$ in the pleural mesothelioma to $87 \%$ in the asbestosis lungs. Except in the lungs of the pleural mesothelioma there was a higher proportion of crocidolite asbestos. The highest proportion of chrysotile fibres was found in the control lungs, and here only approximately $30 \%$ of the total fibre was asbestos.

When the mean percentage constitution of the different types of asbestos is related to asbestosis grade (table 4) the proportions of crocidolite and amosite fibre increase with the severity of asbestosis whereas the proportions of chrysotile and non-asbestos fibres decrease.

Table 5 shows the total fibre count and the proportion of each type of fibre related to the exposure indices. Whereas there is no constant relation, the proportions of amosite and crocidolite tend to rise in those with the higher indices, and for both these types of fibre it is highest in the highest exposure index group. Conversely, the proportion of chrysotile decreases and forms less than $1 \%$ of the total fibres in the lungs of the 10 workers with the highest exposure index. The proportion of mullite also decreases as the index rises.

\section{Discussion}

In the present study the lung asbestos burdens conformed to present day concepts of the epidemiology of asbestos related diseases ${ }^{4}$-namely, that asbestosis is associated with heavy fibre concentrations and mesothelioma with far less. A striking result of the present study is the difference in the degree of asbestosis between the subjects with mesothelioma and those with carcinoma of the lung, the asbestosis being more severe in the latter. This is in agreement with the findings of Wagner et al ${ }^{1}$ when examining the mineral fibre content of the lungs of workers at Devonport dockyard. It is possible that in both studies this finding may have been subject to bias, for whereas all mesotheliomas are likely to be referred to the medical boards, with carcinoma, minor degrees of asbestosis may be overlooked at necropsy and the tumour attributed to smoking. Such bias is unlikely, however, in dockyard or asbestos factory workers.

A further confirmatory finding in this series is that crocidolite and amosite are strongly associated with asbestosis, carcinoma of the lung (among those exposed to asbestos), and mesothelial tumours of both sites, whereas differences between the chrysotile contents of the lungs of the controls and of the subjects exposed to asbestos are less pronounced. This becomes even more significant when allowance is made for the fact that each amosite fibre is at least one hundred times heavier than its chrysotile equivalent. Poorer pulmonary penetration of the curly chrysotile fibres and their physicochemical dissolution in the lung may be responsible for this. ${ }^{56}$ Possibly the damage has been wrought by chrysotile fibres that have subsequently disappeared, but a more likely explanation is that chrysotile plays only a minor part in the causation of the diseases associated with exposure to asbestos dust. This appears to be particularly true of pleural mesothelioma where we found less chrysotile than in the controls. In the other diseases the amount of chrysotile was increased over the controls but in all the diseases the increases in amphibole asbestos were much greater than that of chrysotile. This finding is similar to those reported previously. ${ }^{7-12}$ We believe therefore that chrysotile is the least harmful form of asbestos in every respect and that more emphasis should be laid on the different biological effects of amphibole and serpentine asbestos fibre.

\section{References}

1 Wagner JC, Moncrieff CB, Coles R, Griffiths DM, Munday DE. Correlation between fibre content of the lungs and disease in naval dockyard workers. $\mathrm{Br}$ J Ind Med 1986;43:391-5.

2 Newhouse ML, Berry G, Wagner JC. Mortality of factory workers in east London 1933-80. Br J Ind Med 1985;42:4-11.

3 Newhouse ML. A study of the mortality of workers in an asbestos factory. Br J Ind Med 1969;26:294-301.

4 Becklake MR. Asbestos-related diseases of the lung and other organs: their epidemiology and implications for clinical practice. Am Rev Respir Dis 1976;114:187-227.

5 Timbrell $\mathrm{V}$. Physical factors as aetiological mechanisms. In: Bogovski P, Gilson JC, Timbrell V, Wagner JC, eds. Biological effects of asbestos. Lyon: International Agency for Research on Cancer, 1973:295-303. 
6 Pooley FD. An examination of the fibrous mineral content of asbestos lung tissue from the Canadian chrysotile mining industry. Environ Res 1976;12:281-98.

7 McDonald AD, McDonald JC, Pooley FD. Mineral fibre content of lung in mesothelial tumours in North America. Ann Occup Hyg 1982;26:417-22.

8 Warnock ML, Prescott BT, Kuwahara TJ. Numbers and types of asbestos fibers in subjects with pleural plaques. Am J Pathol 1982;109:37-46.
9 Churg A. Asbestos fibers and pleural plaques in a general autopsy population. Am J Pathol 1982;109:88-96.

10 Churg A. Fiber counting and analysis in the diagnosis of asbestosrelated disease. Hum Pathol 1982;13:381-92.

11 Churg A. Malignant mesothelioma in British Columbia in 1982. Cancer 1985;55:672-4.

12 Roggli VL, Pratt PC, Brody AR. Asbestos content of lung tissue in asbestos associated diseases: a study of 110 cases. Br J Ind Med 1986;43:18-28.

\section{Vancouver style}

All manuscripts submitted to the $B r J$ Ind Med should conform to the uniform requirements for manuscripts submitted to biomedical journals (known as the Vancouver style)

The $\mathrm{Br} J$ Ind Med, together with many other international biomedical journals, has agreed to accept articles prepared in accordance with the Vancouver style. The style (described in full in Br Med J, 24 February 1979, p 532) is intended to standardise requirements for authors.

References should be numbered consecutively in the order in which they are first mentioned in the text by Arabic numerals above the line on each occasion the reference is cited (Manson' confirmed other reports ${ }^{2-5} \ldots$.). In future references to papers submitted to the $B r J$ Ind Med should include: the names of all authors if there are six or less or, if there are more, the first three followed by et al; the title of journal articles or book chapters; the titles of journals abbreviated according to the style of Index Medicus; and the first and final page numbers of the article or chapter.

Examples of common forms of references are:

I International Steering Committee of Medical Editors. Uniform requirements for manuscripts submitted to biomedical journals. Br Med J 1979;1:532-5.

2 Soter NA, Wasserman SI, Austen KF. Cold urticaria: release into the circulation of histamine and eosino-phil chemotactic factor of anaphylaxis during cold challenge. $N$ Engl $J$ Med 1976:294:687-90.

3 Weinstein L, Swartz MN. Pathogenic properties of invading micro-organisms. In: Sodeman WA Jr, Sodeman WA, eds. Pathologic physiology: mechanisms of disease. Philadelphia: W B Saunders, 1974:457-72. 